$\xi=-1$

\title{
Patient Intimacy and Innovation Development to Improve Health Service Performance
}

\author{
Ririn Tri Ratnasari 1,*, Sri Gunawan', Moh Qudzi Fauzi ${ }^{3}$, Dina Fitrisia Septiarini \\ ${ }^{1}$ Deparrment Of Economics, Faculty Of Economics And Business, Universitas Airlianga \\ *Corresponding Author E-Mail: Ririnsari@ Feb.Unair.Ac.Id
}

\begin{abstract}
This study aim to determine the impact of patient intimacy and developing innovations to improve the performance of health services in public health centers which ISO certified in Surabaya. This research was conducted with a quantitative approach survey to patients who are on treatment or health check at public health center. The sampling technique is simple random sampling. Furthermore, the data were processed using partial least square. Result from this study are first, communicaton, social interaction, and compromise as part of a patient intimacy significantly affect the performance of health service in health centers which certified by ISO. Second, communication, compromise, and social interaction as part of the patient intimacy have significant impact on the innovation development of public health centers which certified by ISO. Third, the innovations development significantly affect the performance of health services in primary public health centers which have ISO certificate.
\end{abstract}

Keywords: Patient Intimacy; Innovation Development; Health Service Performance

\section{Introduction}

Patients, as customers of health service, are the controller of health performance produced by health service. The patient also bring their family and friends to go to the primary health service providers such as public health centers (Puskesmas). Therefore, Health Department of Surabaya evaluates the results of the implementation and application of public health center which has ISO certificate along 2010. Evaluations are held at the health service in the Surabaya region often to more discuss about problems that occurred during implementation in the field while providing health services to the community. Minor findings were often in the public health centers in the Surabaya area is about products and services control. The stocks of medicines card were found that did not match to the number of existing drugs, so the amount of drug could not be monitored and the protap of drug delivery to the patient was also still no available (http://dinkes.surabaya.go.id). Much of the research focuses on the adequacy of the logistics of a health service institution.

ISO Consultant of Health Department of Surabaya suggests that public health centers in Surabaya has a degree of success in achieving the certification of ISO 9001: 2008 which is quite encouraging. Public health center in Surabaya classified the best of public health centers in Indonesia who have been certified of ISO. This is because of many variety innovations which done by public health centers in Surabaya, both innovations of the program, document management, as well as the interior design is necessarily break the negative image that the public health center is place of basic health services which is stiff and tend to be static.

However, based on the results of monitoring in the field, besides the advantages of the public health center in Surabaya, the overall performance of the public health center does not make proud, which is still there miss communication among employees, nor employees with patient. The miss problem mostly from the service that still not makimal and the employees were stingy smile to patients (http://dinkes.surabaya.go.id).

Therefore, it is very important to conduct this research, as it relates to the relationship between doctors and nurses when providing health services to patients, especially in terms of patient intimacy as one of the factors that cause (antecedent) of the patients involved in a relationship with the service provider of health (medical team such as doctors and nurses). Ponder et al. ${ }^{(1)}$ mentions that customer intimacy is part of a business strategy based on relationship marketing strategy. Waal and Heijden ${ }^{(2)}$, suggests that customer intimacy also can prevent the end of the relationship between the company and customer. Customer intimacy is the result of customer relationship marketing where customers' emotions tied to a particular brand or service provider company ${ }^{(3)}$. Thus, it needs a management which is able to implement the concept of patient intimacy and developing innovations that can provide improved performance medical team to provide medical services to patients in particular and to the general public in around. Expected by this research, it can encourage the improvement of health services from government hospitals and that hospital become trusted health institution, so it can minimize complaints from the society.

\section{Method}

The approach in this study is a quantitative survey approach and a quantitative descriptive. This approach is done by conducting hypothesis testing, measuring the data, and making conclusions. The type of data in this analysis is cross-sectional, collected through a survey to respondents ie patients who check up their 
health in public health centers which is ISO certified in Surabaya. Secondary data is describing the implementation of patient intimacy strategy and the development of innovation in the public health center that ISO certified in Surabaya. The sampling technique is based on non-random sampling, with the kind of convenience random sampling. This study uses a field survey, 375 respondents carried out to the patient, who was a health examination in health centers certified ISO. The analysis technique used is Partial Least Square (PLS) was first developed by Wold as a general method for estimating path models using latent constructs with multiple indicators ${ }^{(4)}$.

\section{Results And Discussions}

Here is the picture of the test results on the PLS model on the outer stage variables. Here are the outer test the model on each variable Figure 1.

\subsection{Structural Model Phase}

This structural model phase aims to determine whether there is influence between each variables. Tests carried out using t-test. The variable is said to have influence when t statistic is greater than $\mathrm{t}$ table. $\mathrm{T}$ table in this study 1,96. Likewise, if the relationship between the variables then the decision is negative if t-statistic is smaller than t-table. The calculation result can be seen in the following Figure 2.

\subsection{Hypothesis Testing}

Here are the estimated value of each relationship between the variables Table 1. Based on the above table it can be interpreted as follow:

1. Based on the values obtained t value is 2,806 . This value is greater than the value of 1.96 (t-table), so there is a significant influence of communication on the performance of health services.

2. Based on the values obtained $t$ value is 2,186 . This value is greater than the value of 1.96 (t-table), so there is a significant influence of communication on the innovation development.

3. Based on the values obtained t value is 3,064 . This value is greater than the value of 1.96 (t-table), so there is a significant influence of compromise on health service performance.

4. Based on the values obtained t value 3,820 . This value is greater than the value of 1.96 (t-table), so that there is a significant influence innovation development on the health service performance.

5. Based on the values obtained $t$ value is 2,862 . This value is greater than the value of 1.96 (t-table), so there is a significant influence of social interaction on health service performance.

6. Based on the values obtained t value is 3.889 . This value is greater than the value of 1.96 (t-table), so that there is a significant influence of social interaction on the innovation development.

\subsection{Hypothesis Testing}

In this study, there are variables that serve as a mediating variable namely the innovation development. With the mediating variables, the value will be mediation. Relations mediation multiplication coefficient obtained from the direct relationship between the first variable with the second variable. Here is the pattern of indirect relationships in this study were tested using Sobel Test as well as its comparison with immediate effect Table 2 .

The result of the calculation of the indirect effect indicate that there is an indirect effect of variables compromise on the perfor- mance of health services with significant value Sobel 0,041 . The coefficient of indirect influence is 0.085748 . This value is smaller than the direct influence that through the direct effect would be more effective to influence the performance of health services. Then the results of other studies indicate that the mediating role of innovation development of two other variables, namely communication and social interaction was not significant indirect effect on the performance of health services.

\section{Conclusion}

The conclusion that can be drawn from the results of this study are

1. Communication, social interaction, and compromise as part of a patient intimacy significantly affect the performance of health service in public health centers which have ISO certificate.

2. Communication, compromise, and social interaction as part of the patient intimacy significant influence on the innovation development of public health centers which have ISO certificate.

3. Development of innovations significantly affect the performance of health services in primary public health centers which have ISO certificate. Poole-Frenkel emission, leading to a polarity reversion.

\section{Acknowledgement}

This work was supported by Faculty of Economics and Business, Universitas Airlangga.

\section{References}

[1] Ponder N, Ponder N, Bugg Holloway B, Bugg Holloway B, Hansen JD, Hansen JD. The mediating effects of customers' intimacy perceptions on the trust-commitment relationship. Journal of Services Marketing. 2016;30(1):75-87.

[2] de Waal A, de Waal A, van der Heijden B, van der Heijden B. Increasing customer loyalty and customer intimacy by improving the behavior of employees. Journal of Strategy and Management. 2016;9(4):492-510.

[3] Anantadjaya SP, Nawangwulan IM, Pramesty IA, Gunawan GA. Measuring Customers' Intimacy? Evidence from Indonesian Service-Based Companies. 2015.

[4] Ghozali I. Structural equation modeling: Metode alternatif dengan partial least square (pls): Badan Penerbit Universitas Diponegoro; 2008. 